\title{
集合住宅における隙間の評価法に関する研究 \\ EVALUATION METHOD FOR LEAKAGE CHARACTERISTICS \\ OF BUILDING ENVELOPE OPENINGS IN MULTI-FAMILY DWELLINGS
}

\author{
鳥海吉弘*, 倉渕隆**, 兼重 るり子*** \\ Yoshihiro TORIUMI, Takashi KURABUCHI and Ruriko KANESHIGE
}

\begin{abstract}
The leakage characteristics (relationship between air flow rate and pressure difference) of rooms and buildings were compared with measurements from leakage modeling of the constituent openings. Rooms and buildings can be considered as networks of openings that can be combined either in series or in parallel. An exponential equation, commonly known as the power law, has often been used for building envelope openings. The parallel combination model consists of combination of openings in parallel by (long) narrow openings at low Reynolds numbers (e.g. adventitious openings - cracks in walls, etc.) and (short) large openings (e.g. purpose-provided openings - air inlet, etc.). The parallel combination model has precision equivalent to that of the power law, and indication of the crack opening ratio of openings of building envelope is possible. New buildings and retrofitted buildings have high crack opening ratios, and the leakage characteristics are similar to those of narrow openings.
\end{abstract}

Keywords : Multi-family dwellings, Building airtightness, Leakage characteristics, Combination of openings 集合住宅，気密性能，隙間特性，隙間構成

\section{1. はじめに}

1999 年の次世代省エネルギー基準で導入された住宅の相当隙間 面積 C 值（住宅全体隙間の相当開口面積 $\alpha \mathrm{A}$ 值 $\left[\mathrm{cm}^{2}\right]$ /延べ床面 積 $\left[\mathrm{m}^{2}\right]$ ）に関する基準は, 2009 年の基準改正に伴い撤廃されるこ ととなったが，漏気による換気熱損失の削減や計画換気の実現の観 点では, 依然として重要な性能指標である。国際的な動向として, $\mathrm{EU}$ 諸国では 2020 年より前に新築または大規模改修の建築におい て Nearly zero-energy building を普及させるために, 建物とダクト 配管の気密性能は結びつきが強いこと, エネルギー効率のよい換気 システムを使用する必要があることから, 建物は高気密にし, 換気 を正しく行う必要性について触れている ${ }^{1)}$ 。また, 気密測定に関し ては，建物使用時の状態における試験方法や外皮性能の試験方法な ど，目的に応じた試験条件が定められている規格（ISO 9972:2006 2)），試験条件を定めている規格（ASTM E779-10³)）がある。さら に, 改訂された ISO 9972:2014 ${ }^{4)}$ では自国の省エネルギー性能の規 格に適合しているから゙うか, コンプライアンスチェックができる試 験条件も含んでいる。

このように，EU を中心にした外国と日本では気密に対する関心 に若干の温度差があるように思われるが, 日本建築学会では空気環 境運営委員会換気・通風小委員会に気密性能 WG を設置し, 国内外 の気密性能に関する研究動向の調查, 住宅や高層建築物の気密性能
に関する基準・規格，建物設計時に用いられる気密に関する種々の 指針等の調查を行っている ${ }^{5)}$

気密性能の重要性を再認識する必要があるが，従来の隙間特性値 $n$ を用いない相当開口面積 $\alpha \mathrm{A}$ のみで評価する方法では, 例えば改修 工事における対象部位の決定やその効果の確認など，部位別の気密 測定が必要となる場合には，測定に多くの時間を要する。また，室 内外の圧力差が $9.8 \mathrm{~Pa}$ から離れた場合に誤差が生じるため, 圧力差 と通気量の関係式（隙間特性式）の適合性について検討する必要が ある。藤田 ${ }^{6)}$ らは多数室間の隙間の通気率と隙間特性值を, トレー サガスの空気質量収支とガス質量収支から推定しているが，通気量 は通気率に圧力差を底とした隙間特性值の指数を乗じた式(指数式) を用いており, 隙間特性式については検討していない。一方で, Etheridge, Sandberg ${ }^{7)}$ らは複数開口における隙間特性式を, 開口の 形状, レイノルズ数と流量係数, 圧力差の程度等から過去の研究を 含めて広範囲に考察し，開口の合成や各式の適合性についても触れ ている。また, 奥山 ${ }^{8)}$ は実測から各式の係数を推定する際の精度に ついて検討している。実際の住宅（住戸）や建物の隙間は複数の開 口で構成されるため, 隙間特性式の適用には十分な検討が必要であ る。

本研究では，実測值から隙間特性式の適合性について検討する。 また，隙間特性式に多項式モデルを用いることにより，住宅および

\footnotetext{
本論文は, 2013 年度の日本建築学会大会(北海道)にて発表した内容を全面的に見直したものである。

* 東京電機大学理工学部 准教授・博士 (工学)

** 東京理科大学工学部建築学科 教授・博士 (工学)

*** 元東京理科大学学生

Assoc. Prof., School of Science and Engineering, Tokyo Denki University, Dr.Eng.

Prof., Faculty of Eng., Dept. of Architecture, Tokyo University of Science, Dr.Eng.

Formerly Student of Tokyo University of Science
} 
各部位の隙間構成（狭く奥行きのある開口と広く奥行きの浅い開口 の比率）から，住宅における隙間特性值と隙間構成の関係により， 建物竣工年，建物構造・構法（工法）や改修による隙間特性の違い を明らかにし，改修工事の評価等に利用することを目的とする。な お, 建物構造・構法 (工法) によっては隙間の経路（直列・並列ど ちらが支配的か) が異なる可能性があるため, 本論文では対象を集 合住宅とし, 建物構造・構法（工法）による隙間特性の違いについ ては今後の課題とする。

\section{2. 気密性能の測定方法と隙間特性式}

\section{1 気密性能の測定方法}

気密測定では送風機を用いて建物内外に圧力差を生じさせ，通気 量を測定する。測定法には減圧法と加圧法があり, 住宅の気密測定 は室内圧の実状から減圧法で, 部位別測定の場合は隙間のシールを 順次はがしながら測定を繰り返すシール法を加圧法で行うことが多 い。多くの場合, 加圧法の方が減圧法に対し, 相当開口面積 $(\alpha \mathrm{A})$ が 2 割程度の範囲で大きな值となることが知られている ${ }^{9)}$ 。換気方 式によっては正圧・負圧どちらも起こりうる可能性があるため, 本 論文では，加圧法と減圧法，両方の気密測定データを用いる注1)。

\section{2 隙間特性式}

隙間特性式を Table1 に示す。隙間の通過する気流の圧力差と風 量の関係は式(1)の指数式注 2)で表されることが多い。隙間特性は, その開口部形状と同様にレイノルズ数に依存寸ることが知られてい る。開口形状と開口合成のイメージは Fig. 1 に示す。通過気流のレ イノルズ数が低い狭く奥行きのある開口（クラック開ロ）では隙間 特性值 $n$ が 1 に近づき，比較的大きな開口（大開口）は $n$ が 2 に近 づく。また, 指数式では, 同一開口でも通気量, 寸なわち圧力差が 変われば，隙間特性值も変化する ${ }^{7)}$ 。式(2)で示寸平方根の式は，指 数式において $n=2$ としたものであるが，建物（住戸）の隙間特性值 は 2 にならないし, 対象となる圧力差は比較的範囲が広い。また, 実際の建物においては，複数の開口が結合される。そこで，建物の 隙間を，クラック開口（指数式で $n=1 ）$ と大開口（指数式で $n=2 ）$ の並列結合とみなす式(3)の並列結合モデル, 直列結合とみなす式(4) の 2 次式によるあてはめを試みた。並列結合モデルは, クラック開 口と大開口が並列に存在すると仮定し，建物の部位別気密測定のよ うに， $\alpha \mathrm{A}$ を加算的に考える。一方, 2 次式はクラック開口と大開口 が直列に存在すると仮定し，建物の隙間を単一開口とみなす。並列 結合モデルは理論的なエビデンスを持たないが，指数式および平方

\section{Symbols}

\begin{tabular}{|c|c|}
\hline$Q$ & Air flow rate $\left[\mathrm{m}^{3} / \mathrm{h}\right]$ \\
\hline$Q_{0}$ & $\begin{array}{l}\text { Coefficient of the power law, leakage of the opening at } 1 \mathrm{~Pa} \\
{\left[\mathrm{~m}^{3} / \mathrm{h}\right]}\end{array}$ \\
\hline$\Delta P$ & Induced pressure difference $[\mathrm{Pa}]$ \\
\hline$n$ & $\begin{array}{l}\text { Coefficient of leakage characteristics, exponent in the power } \\
\text { law }\end{array}$ \\
\hline$\alpha$ & Discharge coefficient \\
\hline A & Area $\left[\mathrm{cm}^{2}\right]$ \\
\hline$\alpha \mathrm{A}$ & Specific effective leakage area at $9.8 \mathrm{~Pa}\left(\mathrm{ELA}_{10}\right)\left[\mathrm{cm}^{2}\right]$ \\
\hline$\rho$ & Air density $\left[\mathrm{kg} / \mathrm{m}^{3}\right]$ \\
\hline$\alpha \mathrm{A}_{\mathrm{N}}$ & $\mathrm{ELA}_{10}$ of narrow opening at low Reynolds numbers $\left[\mathrm{cm}^{2}\right]$ \\
\hline$\alpha \mathrm{A}_{\mathrm{L}}$ & $\mathrm{ELA}_{10}$ of large opening $\left[\mathrm{cm}^{2}\right]$ \\
\hline$a, b, c, d, D$ & Experiment coefficient \\
\hline
\end{tabular}

Table 1 Models for leakage

Power law for narrow openings

$$
\begin{aligned}
& Q=Q_{0} \Delta P^{1 / n} \\
& \Delta P=D Q^{n}
\end{aligned}
$$

Square law

$$
Q=\frac{3600}{10000} \alpha A \sqrt{\frac{2}{\rho} \Delta P}
$$

Parallel combination model

$$
\begin{aligned}
Q & =a \Delta P+b \sqrt{\Delta P} \\
& =\frac{3600}{10000} \sqrt{\frac{2}{\rho} \Delta P}\left(\alpha A_{N} \sqrt{\frac{\Delta P}{9.8}}+\alpha A_{L}\right)
\end{aligned}
$$

Quadratic equation $\Delta P=c Q+d Q^{2}$

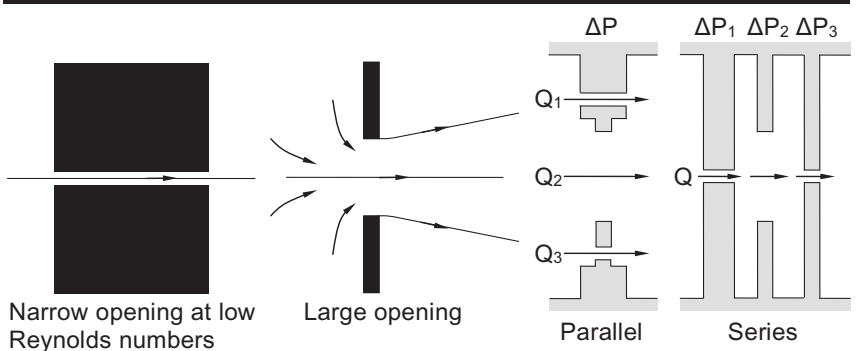

Fig.1 Geometry and combination of openings

根の式における $\alpha \mathrm{A}$ が， $\alpha \mathrm{A}=\alpha \mathrm{A}_{\mathrm{N}}+\alpha \mathrm{A}_{\mathrm{L}}$ の関係で表され（式(3a)）， 相当開口面積がクラック開口と大開口の合計となる点が特徴的であ る。なお, 2 次式では, $c$ は粘性係数, $d$ は密度に比例する ${ }^{7)}$ 。

\begin{tabular}{|c|c|c|c|c|c|c|c|c|}
\hline & \#ID & Location & $\begin{array}{l}\begin{array}{l}\text { Year Built } \\
\text { (Retrofitted) }\end{array} \\
\end{array}$ & Type & Structure & Stories & Units & Remarks \\
\hline Apartment house $\mathrm{A}$ & A & Kanagawa & $\begin{array}{l}1971 \\
(2006)\end{array}$ & Central corridor & $\begin{array}{l}\text { Steel reinforced } \\
\text { concrete (SRC) }\end{array}$ & 15 & 143 & Windows were retrofitted. \\
\hline Apartment house B & B & Tokyo & $\begin{array}{l}1967 \\
(2006)\end{array}$ & Stairs room & $\begin{array}{l}\text { Reinforced } \\
\text { concrete (RC) }\end{array}$ & 5 & 30 & $\begin{array}{l}\text { Windows and entrance door were retro- } \\
\text { fitted. (Steel window frames before } \\
\text { retrofitting) }\end{array}$ \\
\hline Apartment house $\mathrm{C}$ & $\mathrm{C}$ & Kanagawa & $\begin{array}{l}1970 \\
(2007)\end{array}$ & $\begin{array}{l}\text { Side corridor (Skip } \\
\text { floor)+Stairs room }\end{array}$ & $\mathrm{RC}$ & 10 & 97 & Windows were retrofitted. \\
\hline Apartment house D & $\mathrm{D}$ & Kanagawa & 2004 & Side corridor & $\mathrm{RC}$ & 5 & 101 & \\
\hline Apartment house E & E & Tokyo & 2007 & Void & $\mathrm{RC}$ & 28 & 329 & Double glazed soundproof windows \\
\hline Apartment house $\mathrm{F}$ & $\mathrm{F}$ & Kanagawa & 2003 & Side corridor & $\mathrm{RC}$ & 7 & 110 & \\
\hline Apartment house G & G & Tokyo & 1979 & Side corridor & $\mathrm{RC}$ & 12 & 158 & \\
\hline Apartment house $\mathrm{H}$ & $\mathrm{H}$ & Tokyo & 1961 & Stairs room & $\mathrm{RC}$ & 4 & 32 & \\
\hline
\end{tabular}

\section{3．実測による隙間特性式の比較}

\section{1 実測概要}

実測は, Table 2 に示す 1961 年から 2007 年に建設された 8 物件

Table 2 Building characteristics of studied apartments 


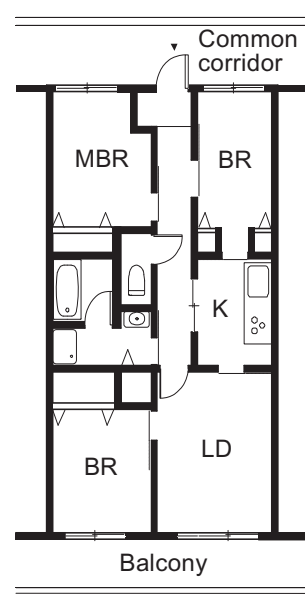

Fig.2 Plan of dwelling unit F1 (apartment F)
Table 3 Measured data of dwelling unit F1 $\begin{array}{llllll}\Delta \boldsymbol{P}[\mathbf{P a}] & 21.1 & 31.6 & 39.9 & 49.5 & 59.8\end{array}$ \begin{tabular}{llllll}
$\boldsymbol{Q}\left[\mathrm{m}^{3} / \mathbf{h}\right]$ & 239 & 312 & 385 & 424 & 473 \\
\hline
\end{tabular}

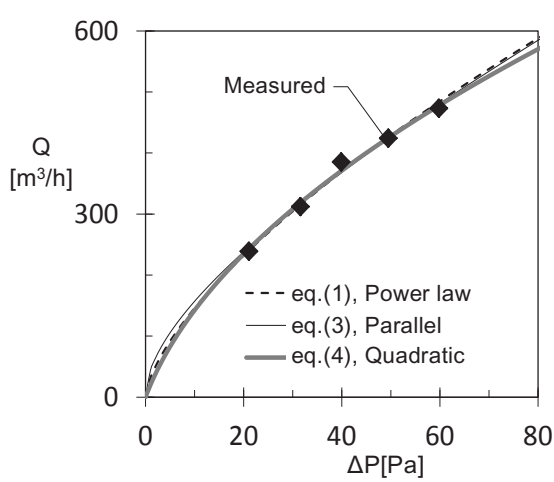

Fig.3 Fitting of equations with measured data (dwelling unit F1)

Table 4 Measured data of determination of air leakage by fan pressurization method

\begin{tabular}{|c|c|c|c|c|c|c|}
\hline ID & $\begin{array}{l}\mathrm{Ti}[\mathbf{K}] \\
\left(\left[^{\circ} \mathrm{C}\right]\right)\end{array}$ & $\begin{array}{l}\text { To[K] } \\
\left(\left[^{\circ} \mathrm{C}\right]\right)\end{array}$ & $\begin{array}{l}\text { Floor } \\
\text { area }\left[\mathrm{m}^{2}\right]\end{array}$ & $\begin{array}{l}\Delta P \\
{[\mathrm{~Pa}]}\end{array}$ & $\begin{array}{l}Q \\
{\left[\mathrm{~m}^{3} / \mathrm{h}\right]}\end{array}$ & $\begin{array}{l}\text { Method } \\
\text { (Remarks) }\end{array}$ \\
\hline$\overline{\mathrm{A} 1}$ & $\begin{array}{l}294.1 \\
(20.9)\end{array}$ & $\begin{array}{l}290.6 \\
(17.4)\end{array}$ & 42.7 & $\begin{array}{r}8.7 \\
20.7 \\
28.9 \\
40.6 \\
50.7 \\
60.0\end{array}$ & $\begin{array}{l}316 \\
519 \\
628 \\
760 \\
858 \\
952\end{array}$ & Pressurization \\
\hline A1r & $\begin{array}{l}293.8 \\
(20.6)\end{array}$ & $\begin{array}{l}292.7 \\
(19.5)\end{array}$ & 42.7 & $\begin{array}{r}9.3 \\
21.2 \\
31.8 \\
40.3 \\
49.2 \\
58.4\end{array}$ & $\begin{array}{l}258 \\
437 \\
554 \\
631 \\
706 \\
778\end{array}$ & $\begin{array}{l}\text { Pressurization } \\
\text { (After retrofitting) }\end{array}$ \\
\hline $\mathrm{A} 2$ & $\begin{array}{l}294.8 \\
(21.6)\end{array}$ & $\begin{array}{l}297.3 \\
(24.1)\end{array}$ & 42.7 & $\begin{array}{l}19.1 \\
29.8 \\
41.2 \\
48.8 \\
62.0\end{array}$ & $\begin{array}{l}393 \\
519 \\
631 \\
682 \\
795\end{array}$ & Pressurization \\
\hline $\mathrm{A} 2 \mathrm{r}$ & $\begin{array}{l}292.0 \\
(18.8)\end{array}$ & $\begin{array}{l}287.2 \\
(14.0)\end{array}$ & 42.7 & $\begin{array}{l}20.7 \\
29.9 \\
39.9 \\
50.6 \\
60.2\end{array}$ & $\begin{array}{l}292 \\
369 \\
440 \\
508 \\
555\end{array}$ & $\begin{array}{l}\text { Pressurization } \\
\text { (After retrofitting) }\end{array}$ \\
\hline B1 & $\begin{array}{l}285.4 \\
(12.2)\end{array}$ & $\begin{array}{l}280.9 \\
(7.7)\end{array}$ & 43.3 & $\begin{array}{r}9.1 \\
17.7 \\
28.3 \\
36.9 \\
45.1 \\
52.0\end{array}$ & $\begin{array}{r}476 \\
670 \\
869 \\
1007 \\
1111 \\
1195\end{array}$ & Depressurization \\
\hline $\mathrm{B} 2 \mathrm{r}$ & $\begin{array}{l}286.7 \\
(13.5)\end{array}$ & $\begin{array}{l}282.0 \\
(8.8)\end{array}$ & 43.3 & $\begin{array}{r}9.7 \\
19.6 \\
30.3 \\
41.8 \\
49.8 \\
60.3\end{array}$ & $\begin{array}{l}176 \\
266 \\
337 \\
402 \\
442 \\
491\end{array}$ & $\begin{array}{l}\text { Depressurization } \\
\text { (After retrofitting) }\end{array}$ \\
\hline $\mathrm{C} 1$ & $\begin{array}{l}293.4 \\
(20.2)\end{array}$ & $\begin{array}{l}290.8 \\
(17.6)\end{array}$ & 43.6 & $\begin{array}{l}10.1 \\
19.6 \\
29.5 \\
39.8 \\
50.6\end{array}$ & $\begin{array}{l}228 \\
325 \\
435 \\
519 \\
611\end{array}$ & Pressurization \\
\hline C1r & $\begin{array}{l}292.6 \\
(19.4)\end{array}$ & $\begin{array}{l}290.4 \\
(17.2)\end{array}$ & 43.6 & $\begin{array}{l}10.6 \\
19.6 \\
31.6 \\
40.8 \\
47.7\end{array}$ & $\begin{array}{l}175 \\
266 \\
361 \\
417 \\
438\end{array}$ & $\begin{array}{l}\text { Pressurization } \\
\text { (After retrofitting) }\end{array}$ \\
\hline
\end{tabular}

の集合住宅を対象とした。構造は鉄筋コンクリート造または鉄骨鉄 筋コンクリート造の湿式工法注 3) で, サッシまわりを改修したストッ
Table 4 (Continued)

\begin{tabular}{|c|c|c|c|c|c|c|}
\hline ID & $\begin{array}{l}\mathrm{Ti}[\mathrm{K}] \\
\left(\left[^{\circ} \mathrm{C}\right]\right)\end{array}$ & $\begin{array}{l}\text { To }[\mathrm{K}] \\
\left(\left[{ }^{\circ} \mathrm{C}\right]\right)\end{array}$ & $\begin{array}{l}\text { Floor } \\
\text { area }\left[\mathrm{m}^{2}\right]\end{array}$ & $\begin{array}{l}\Delta P \\
{[\mathrm{~Pa}]}\end{array}$ & $\begin{array}{l}Q \\
{\left[\mathrm{~m}^{3} / \mathrm{h}\right]}\end{array}$ & $\begin{array}{l}\text { Method } \\
\text { (Remarks) }\end{array}$ \\
\hline $\mathrm{C} 2 \mathrm{r}$ & $\begin{array}{l}293.9 \\
(20.7)\end{array}$ & $\begin{array}{l}290.8 \\
(17.6)\end{array}$ & 44.0 & $\begin{array}{r}9.9 \\
18.8 \\
30.7 \\
39.7 \\
51.1 \\
\end{array}$ & $\begin{array}{l}190 \\
295 \\
399 \\
462 \\
541 \\
\end{array}$ & $\begin{array}{l}\text { Pressurization } \\
\text { (After retrofitting) }\end{array}$ \\
\hline $\mathrm{C} 3 \mathrm{r}$ & $\begin{array}{l}287.3 \\
(14.1)\end{array}$ & $\begin{array}{l}287.0 \\
(13.8)\end{array}$ & 43.3 & $\begin{array}{l}10.0 \\
19.1 \\
29.1 \\
41.0 \\
50.6 \\
\end{array}$ & $\begin{array}{l}126 \\
202 \\
262 \\
323 \\
358 \\
\end{array}$ & $\begin{array}{l}\text { Pressurization } \\
\text { (After retrofitting) }\end{array}$ \\
\hline $\mathrm{C} 4$ & $\begin{array}{l}286.1 \\
(12.9)\end{array}$ & $\begin{array}{l}283.5 \\
(10.3)\end{array}$ & 43.3 & $\begin{array}{l}18.2 \\
26.0 \\
33.8 \\
43.4 \\
50.5 \\
\end{array}$ & $\begin{array}{l}358 \\
453 \\
547 \\
633 \\
691 \\
\end{array}$ & Pressurization \\
\hline D1 & $\begin{array}{l}289.7 \\
(16.5)\end{array}$ & $\begin{array}{l}282.5 \\
(9.3)\end{array}$ & 73.7 & $\begin{array}{l}31.3 \\
41.5 \\
53.6 \\
65.1 \\
73.8 \\
84.8 \\
97.5\end{array}$ & $\begin{array}{l}159 \\
202 \\
251 \\
282 \\
321 \\
360 \\
401\end{array}$ & Pressurization \\
\hline E3 & $\begin{array}{l}289.6 \\
(16.4)\end{array}$ & $\begin{array}{l}282.9 \\
(9.7)\end{array}$ & 80.0 & $\begin{array}{r}8.0 \\
16.9 \\
28.8 \\
48.2 \\
67.0 \\
82.1 \\
\end{array}$ & $\begin{array}{r}61 \\
105 \\
152 \\
201 \\
246 \\
293 \\
\end{array}$ & Pressurization \\
\hline E4 & $\begin{array}{l}292.8 \\
(19.6)\end{array}$ & $\begin{array}{l}285.0 \\
(11.8)\end{array}$ & 63.0 & $\begin{array}{r}48.6 \\
60.3 \\
69.7 \\
81.5 \\
91.1 \\
110.1 \\
\end{array}$ & $\begin{array}{l}143 \\
180 \\
193 \\
215 \\
239 \\
282 \\
\end{array}$ & Pressurization \\
\hline E5 & $\begin{array}{l}291.1 \\
(17.9)\end{array}$ & $\begin{array}{l}281.7 \\
(8.5)\end{array}$ & 65.0 & $\begin{array}{l}27.8 \\
33.9 \\
44.9 \\
59.6 \\
83.0 \\
98.0 \\
\end{array}$ & $\begin{array}{r}85 \\
93 \\
119 \\
154 \\
196 \\
217 \\
\end{array}$ & Pressurization \\
\hline F1 & $\begin{array}{l}305.2 \\
(32.0)\end{array}$ & $\begin{array}{l}304.9 \\
(31.7)\end{array}$ & 66.0 & $\begin{array}{l}21.1 \\
31.6 \\
39.9 \\
49.5 \\
59.8 \\
\end{array}$ & $\begin{array}{l}239 \\
312 \\
385 \\
424 \\
473 \\
\end{array}$ & Pressurization \\
\hline G1 & $\begin{array}{l}298.2 \\
(25.0)\end{array}$ & $\begin{array}{l}296.8 \\
(23.6)\end{array}$ & 45.5 & $\begin{array}{l}10.5 \\
20.1 \\
28.2 \\
39.0 \\
51.8 \\
\end{array}$ & $\begin{array}{l}310 \\
429 \\
518 \\
620 \\
720 \\
\end{array}$ & Depressurization \\
\hline G2 & $\begin{array}{l}299.5 \\
(26.3)\end{array}$ & $\begin{array}{l}298.2 \\
(25.0)\end{array}$ & 45.5 & $\begin{array}{l}18.4 \\
25.1 \\
33.5 \\
43.3 \\
51.3 \\
\end{array}$ & $\begin{array}{l}319 \\
376 \\
444 \\
507 \\
566 \\
\end{array}$ & Depressurization \\
\hline H1 & $\begin{array}{l}298.1 \\
(24.9)\end{array}$ & $\begin{array}{l}294.1 \\
(20.9)\end{array}$ & 26.5 & $\begin{array}{r}9.3 \\
14.5 \\
19.3 \\
25.8 \\
29.6 \\
\end{array}$ & $\begin{array}{r}498 \\
655 \\
777 \\
923 \\
1000\end{array}$ & Depressurization \\
\hline $\mathrm{H} 2$ & $\begin{array}{l}299.5 \\
(26.3)\end{array}$ & $\begin{array}{l}297.6 \\
(24.4)\end{array}$ & 26.5 & $\begin{array}{l}10.6 \\
20.4 \\
31.3 \\
42.1 \\
50.5\end{array}$ & $\begin{array}{l}329 \\
481 \\
622 \\
744 \\
822 \\
\end{array}$ & Depressurization \\
\hline
\end{tabular}

Ti: Indoor air temperature, To: Outdoor air temperature.

Converted the measured flow rate to air flow rate, $Q$

Subscript $r$ in the ID shows after retrofitting.

ク集合住宅注4)や，ボイド型超高層集合住宅を含んでいる。代表的な 片廊下型の $\mathrm{F}$ 集合住宅のプランを Fig.2 に示す。なお，測定は住戸 


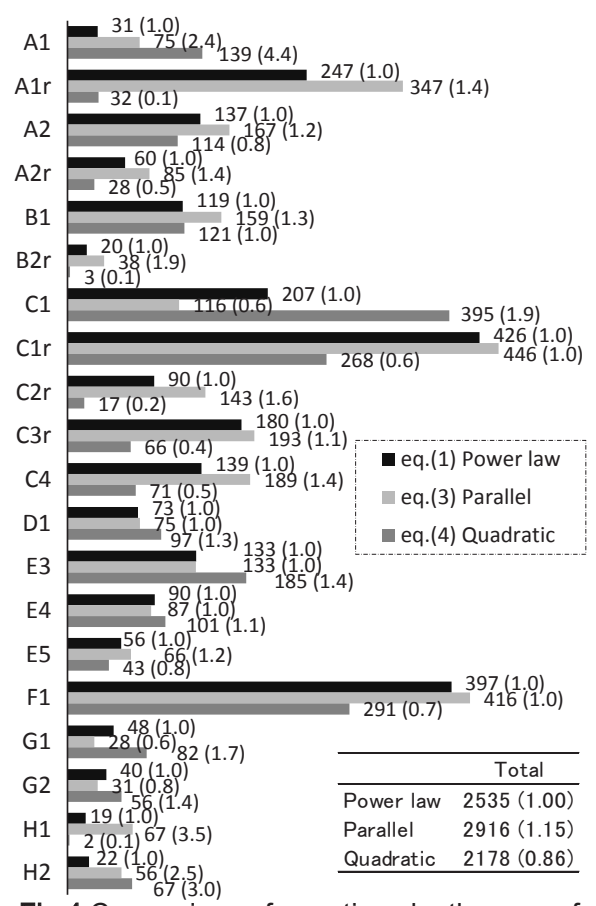

Fig. 4 Comparison of equations by the sum of squares of the residual: (Normalised values with the value of the power law)
Table 5 Correspondence of the values (ELA 10 and $\alpha \mathrm{A}_{N}+\alpha \mathrm{A}_{\mathrm{L}}, \mathrm{n}$ and $\left.\alpha \mathrm{A}_{N} /\left(\alpha \mathrm{A}_{N}+\alpha \mathrm{A}_{\mathrm{L}}\right)\right)$ in two equations

\begin{tabular}{|c|c|c|c|c|c|c|c|c|c|}
\hline \multirow[t]{2}{*}{ ID } & \multicolumn{3}{|c|}{ eq.(1) Power law } & \multicolumn{6}{|c|}{ eq.(3) Parallel } \\
\hline & $\begin{array}{l}\alpha \mathrm{A}\left(\mathbf{E L A}_{10}\right) \\
{\left[\mathrm{cm}^{2}\right]}\end{array}$ & $n$ & $\begin{array}{l}\operatorname{ELA}_{\mathbf{F} 10} * \\
{\left[\mathrm{~cm}^{2} / \mathbf{m}^{2}\right]} \\
\end{array}$ & $a$ & $b$ & $\begin{array}{l}\alpha \mathbf{A}_{N} \\
{\left[\mathrm{~cm}^{2}\right]} \\
\end{array}$ & $\begin{array}{l}\alpha \mathbf{A}_{\mathbf{L}} \\
{\left[\mathrm{cm}^{2}\right]} \\
\end{array}$ & $\begin{array}{l}\alpha \mathrm{A}_{\mathrm{N}}+\alpha \mathrm{A}_{\mathrm{L}} \\
{\left[\mathrm{cm}^{2}\right]} \\
\end{array}$ & $\begin{array}{l}\alpha \mathbf{A}_{N} / \\
\left(\alpha \mathbf{A}_{N}+\alpha \mathbf{A}_{L}\right)\end{array}$ \\
\hline A1 & 233 & 1.76 & 5.5 & 2.88 & 100.56 & 19 & 216 & 236 & $8 \%$ \\
\hline A1r & 186 & 1.67 & 4.4 & 2.92 & 80.30 & 20 & 173 & 193 & $10 \%$ \\
\hline $\mathrm{A} 2$ & 183 & 1.68 & 4.3 & 2.78 & 79.15 & 19 & 170 & 189 & $10 \%$ \\
\hline $\mathrm{A} 2 \mathrm{r}$ & 129 & 1.65 & 3.0 & 2.17 & 55.39 & 15 & 120 & 134 & $11 \%$ \\
\hline B1 & 347 & 1.88 & 8.0 & 1.95 & 152.42 & 13 & 336 & 349 & $4 \%$ \\
\hline $\mathrm{B} 2 \mathrm{r}$ & 125 & 1.79 & 2.9 & 1.16 & 54.43 & 8 & 120 & 128 & $6 \%$ \\
\hline $\mathrm{C} 1$ & 151 & 1.62 & 3.5 & 3.94 & 57.76 & 27 & 124 & 151 & $18 \%$ \\
\hline $\mathrm{C} 1 \mathrm{r}$ & 117 & 1.60 & 2.7 & 2.25 & 49.67 & 15 & 107 & 122 & $12 \%$ \\
\hline $\mathrm{C} 2 \mathrm{r}$ & 132 & 1.57 & 3.0 & 3.26 & 52.85 & 22 & 114 & 136 & $16 \%$ \\
\hline $\mathrm{C} 3 \mathrm{r}$ & 89 & 1.54 & 2.0 & 2.14 & 36.02 & 15 & 78 & 93 & $16 \%$ \\
\hline $\mathrm{C} 4$ & 168 & 1.54 & 3.9 & 4.49 & 66.19 & 31 & 144 & 175 & $18 \%$ \\
\hline D1 & 43 & 1.23 & 0.6 & 2.78 & 13.26 & 19 & 29 & 48 & $40 \%$ \\
\hline E3 & 50 & 1.52 & 0.6 & 1.34 & 19.79 & 9 & 43 & 52 & $18 \%$ \\
\hline E4 & 28 & 1.24 & 0.4 & 1.63 & 9.57 & 11 & 21 & 32 & $35 \%$ \\
\hline E5 & 25 & 1.28 & 0.4 & 1.37 & 8.75 & 9 & 19 & 28 & $33 \%$ \\
\hline F1 & 97 & 1.49 & 1.5 & 2.71 & 41.08 & 18 & 87 & 105 & $17 \%$ \\
\hline G1 & 203 & 1.88 & 4.5 & 1.34 & 90.51 & 9 & 194 & 203 & $4 \%$ \\
\hline G2 & 153 & 1.80 & 3.4 & 1.58 & 67.29 & 11 & 144 & 154 & $7 \%$ \\
\hline H1 & 355 & 1.66 & 13.4 & 8.09 & 140.40 & 55 & 302 & 357 & $15 \%$ \\
\hline $\mathrm{H} 2$ & 215 & 1.70 & 8.1 & 3.74 & 89.73 & 25 & 192 & 217 & $12 \%$ \\
\hline
\end{tabular}

* $\quad$ ELA $_{\mathrm{F} 10}$ means specific effective leakage area per the floor area. $\mathrm{ELA}_{\mathrm{F} 10}=\mathrm{ELA}_{10} /$ Floor area
の窻に住宅用気密測定器を設置し, 日常生活下で出現しうる圧力差 で，ストック改修住宅については改修の前後で測定を行った。

\section{2 隙間特性式の適用}

測定值である圧力差 $\Delta P$ と通気量 $Q$ に, 式(1)の指数式, 式(3)の並 列結合モデル, 式(4)の 2 次式をあてはめ, 最小二乗法により各係数

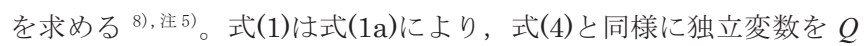
とし，式(3)では $\Delta P$ としている。測定結果の一例を Table3 に，隙 間特性式にあてはめた結果を Fig. 3 に示す。圧力差の測定範囲では 各式とも測定值とよく対応しており差がみられないが, 範囲外では 各式に差異がみられる。そのため, 圧力差の測定範囲は広い方が好 ましい。日常生活を考慮して圧力差の測定範囲は $10 \sim 50 \mathrm{~Pa}^{9)}$, 高気 密住宅では $30 \sim 100 \mathrm{~Pa}$ 程度 ${ }^{10)}$ と想定される。

\section{3 隙間特性式の適合性}

各式の適合性の比較に使用する Table2 に示した集合住宅におけ る住戸の気密測定結果を Table 4 に示す。各式の適合性は, 測定值 $Q$ に対する線形残差二乗和の比較により検討する。分析結果を Fig.4 に示す。カッコ内の数值は, 各式における残差二乗和の值を, 指数 式の残差二乗和で基準化したものである。測定值と最も対応が良い のは 2 次式となった。並列結合モデルは, 2 次式に対して, 指数式 に近い特性を持ち, 適合性に関しても遜色のないレベルである。そ こで指数式に加え, 測定結果の物理的な解釈が容易な並列結合モデ ルによる検討を行うことにする。

\section{4. 集合住宅における隙間特性の評価}

\section{1 住戸の隙間特性}

隙間特性式の適合性の検証に用いた集合住宅 8 物件 20 住戸を対 象とし，指数式と並列結合モデルによる隙間特性の評価を行った (Table5)。表中の $\mathrm{ELA}_{\mathrm{F} 10}$ (Specific effective leakage area per the floor area）は $\mathrm{C}$ 值を表し, $\alpha \mathrm{A}_{\mathrm{N}} /\left(\alpha \mathrm{A}_{\mathrm{N}}+\alpha \mathrm{A}_{\mathrm{L}}\right)$ はクラック開口比率と定
義し, 並列結合モデルにより算出した総相当開口面積（クラック開 口と大開口の相当開口面積の和： $\alpha \mathrm{A}_{\mathrm{N}}+\alpha \mathrm{A}_{\mathrm{L}}$ ）における $\alpha \mathrm{A}_{\mathrm{N}}$ の占める 割合を示す。指数式により算出した $\alpha \mathrm{A}$ と並列結合モデルにより算 出した $\alpha \mathrm{A}_{\mathrm{N}}+\alpha \mathrm{A}_{\mathrm{L}}$ はよく対応している。

改修の効果について, A 集合住宅の A1 住戸では 2 割, A2 住戸で は 3 割, B 集合住宅では 6 割（同一プランの B1・B2r 住戸での比 較), $\mathrm{C}$ 集合住宅でも 3 割， $\alpha \mathrm{A}$ が減少している。B 集合住宅は改修 により鋼製空枠をアルミ製空枠に変更し, 加えて玄関ドアをエアタ イト仕様に変更していることが要因となっている。また，隙間特性 值 $n$ は僅かに小さくなり, クラック開口比率は微増している。一方, $\mathrm{E}$ 集合住宅の $\mathrm{E} 4$ ・ E5 住戸に対して E3 住戸の $\alpha \mathrm{A}$ が比較的大きい のはプランの違いによるものである。 E4・E5 住戸は一般的なプラ ンであるが，E3 住戸は建物平面計画における隅角部に設けられた

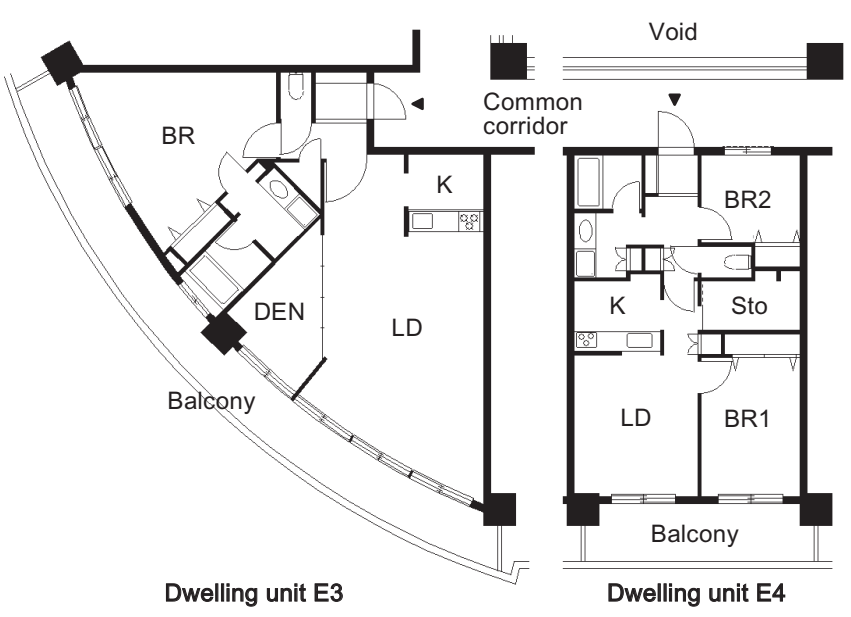

Fig.5 Plan of the dwelling unit of void type apartment house E

ワイドフロンテージ住戸であり , バルコニー側が全面掃出し空にな っている（Fig.5）。また, E3 住戸のクラック開口比率は 18\%で, 
E4 住戸の 35\%，E5 住戸の 33\%に対して小さくなっている。

竣工年による違いでは施工精度の進歩に伴う気密性の向上が一般 に知られているが, 隙間構成の変化にも年代による特徴が顕著に表 れた。1960〜1970 年代のストック集合住宅ではクラック開口比率 が 4〜18\%だが, 2000 年以降の集合住宅では $17 〜 40 \%$ と高い值と なっている。

\section{2 部位別の隙間構成}

空, 玄関ドア, 給気口など, 住戸の各部位について, 隙間構成に 関する評価を行う。並列結合モデルにより, 当該部位のシールして いない状態で算出した各相当開口面積から, シールをした状態での 相当開口面積を減じて, 各部位の $\alpha \mathrm{A}_{\mathrm{N}}, \alpha \mathrm{A}_{\mathrm{L}}$ を求めた (Table6)。そ れぞれの值が小さいため, 誤差が顕在化しやすい。表中の $\alpha \mathrm{A}_{\mathrm{L}} /\left(\alpha \mathrm{A}_{\mathrm{N}}+\alpha \mathrm{A}_{\mathrm{L}}\right)$ を大開口比率と定義し, 1 からクラック開口比率を減 じた值を指す。大開口比率は空部で $67 \sim 86 \%$, 玄関ドアで $85 \%$ 程度 となった。これら開口部まわりの隙間形状は, 開口幅は狭いが奥行 き寸法も小さいため, 大開口に近い特性を持つと予想される。一方, 住戸において, 給気口など意図的に設置した開口を除く, 開口部ま わり以外 (バックグランド) の隙間は「躯体・その他」であり, 住 戸の隙間特性から, レイノルズ数の小さいクラック開口に近い特性 を持つと思われる。2000 年以降の集合住宅や, 改修集合住宅のクラ ック開口比率が大きいのは, 空や玄関ドアなど, 開口部まわりの相 当開口面積が小さいことに起因している。なお, 給気口の大開口比 率は，一般的なもので $99 \%$ ，防音型で $91 \%$ となった。

\section{3 隙間特性値と相当隙間面積・クラック開口比率}

Table5 における相当隙間面積 (C 值, ELA $A_{F 10}$ ) と隙間特性值 $n$ の 関係を Fig.6 に示す。強い相関はみられない。前述の E3 住戸と E4・ $\mathrm{E} 5$ 住戸の関係のように, $\mathrm{C}$ 值が同等の值でも, 開口部まわりとバッ クグランドの隙間特性が異なるため, 空開口面積の床面積に対する 割合によって隙間特性值は変化する。また, C 值が同じでも構造種 別や構法が異なれば，隙間特性が変化することも考えられる。

Fig.7 に隙間特性值 $n$ とクラック開口比率の関係を 3 次式で表し た結果を示す。Table5 の結果に, $n$ が 1 のときにクラック開口比率 が $100 \%, n$ が 2 のときに $0 \%$, の 2 点を通過する制約条件を加えて 最小二乗法により各係数を算出した。気密性能の測定法によらず測 定值は 3 次の回帰式に対応している。ストック $(+)$, ストック改 修 (ム)，2003～2007 年新築（の）の順に隙間特性值が小さくなり, クラック開口比率は大きくなっている。 RC・SRC 集合住宅におい て式(5)を用いれば, 隙間特性值を代入するだけでクラック開口比率 を推定することが可能となり, 隙間特性值と隙間構成の関係から, 開口部まわりの改修による有効性を検討し, 改修による隙間特性の 変化を確認することができる。

\section{5.まとめ}

本論文では, 集合住宅における住戸および各部位の隙間特性の評 価方法に着目し, 以下の知見を得た。

隙間特性を評価する上で, 相当開口面積をクラック開口（狭く, 開口寸法に対して奥行寸法が大きな開口）と大開口（開口寸法が大 きく, 奥行きの浅い開口)に分割できる並列結合モデルを提案した。 気密測定における実測值を利用して各隙間特性式を評価した結果, 最も適合性が良かったのは, クラック開口と大開口を直列結合とみ
Table 6 Leakage component for each part in buildings

\begin{tabular}{|c|c|c|c|c|c|c|c|c|}
\hline & \multicolumn{3}{|c|}{$\begin{array}{l}\text { Double sliding } \\
\text { windows }\end{array}$} & \multicolumn{3}{|c|}{ Entrance doors } & \multicolumn{2}{|c|}{ Air inlets } \\
\hline & C1 & C3r ${ }^{* 1}$ & D1 ${ }^{* 2}$ & D1 ${ }^{* 3}$ & F1 ${ }^{* 3}$ & E5 & D1 & $\mathbf{E 3}^{* 4}$ \\
\hline$\alpha A_{N}\left[\mathrm{~cm}^{2}\right]$ & 0.9 & 2.6 & 4.1 & 2.4 & 4.4 & 1.6 & 0.1 & 0.6 \\
\hline$\alpha \mathrm{A}_{\mathrm{L}}\left[\mathrm{cm}^{2}\right]$ & 5.7 & 5.3 & 11.0 & 12.5 & 22.2 & 9.3 & 9.3 & 6.0 \\
\hline$\alpha \mathbf{A}_{\mathbf{N}} /\left(\alpha \mathbf{A}_{\mathbf{N}}+\alpha \mathbf{A}_{\mathbf{L}}\right)$ & $14 \%$ & $33 \%$ & $27 \%$ & $16 \%$ & $16 \%$ & $15 \%$ & $1 \%$ & $9 \%$ \\
\hline$\alpha \mathbf{A}_{\mathbf{L}} /\left(\alpha \mathbf{A}_{\mathrm{N}}+\alpha \mathbf{A}_{\mathbf{L}}\right)$ & $86 \%$ & $67 \%$ & $73 \%$ & $84 \%$ & $84 \%$ & $85 \%$ & $99 \%$ & $91 \%$ \\
\hline \multicolumn{9}{|c|}{ *1 $\quad$ After retrofitting } \\
\hline Dust-outlet wi & & & & & & & & \\
\hline The entrance c & oor is & . & & & & & & \\
\hline Soundproof ty & air $\mathrm{i}$ & & & & & & & \\
\hline
\end{tabular}

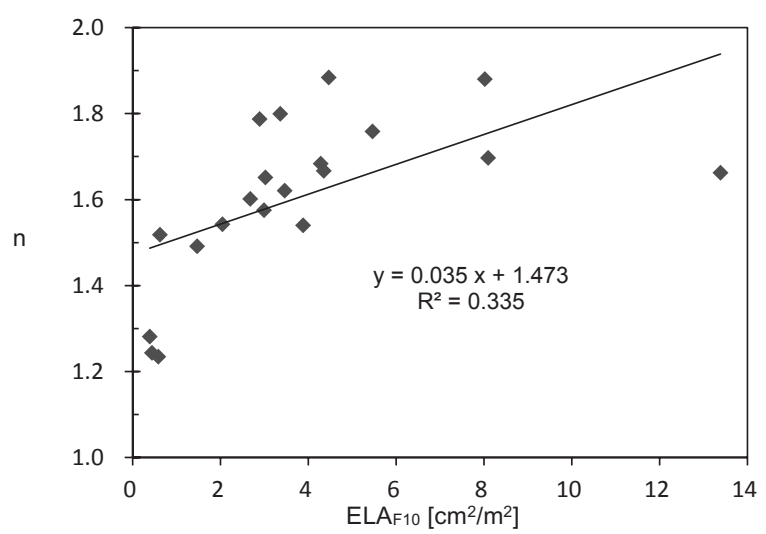

Fig.6 Relation between specific effective leakage area per the floor area and "power law" exponent $n$

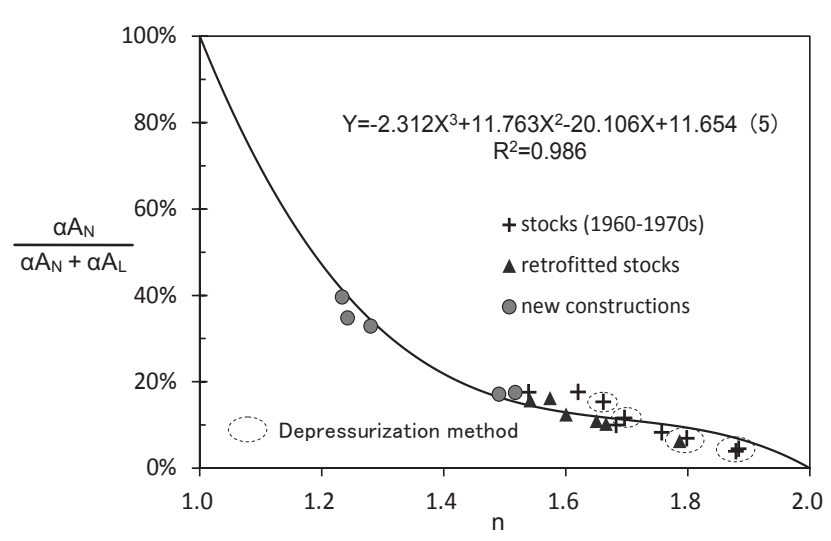

Fig.7 Variation of the specific effective leakage area of narrow opening with "power law" exponent $n$

なす 2 次式であり，並列結合モデルは指数式に近い特性を示した。 1960１970 年代のストック集合住宅において，並列結合モデル により算出した相当開口面積に対するクラック開口の相当開口面積 が占める割合 (クラック開口比率) は 5 20\%程度であったが, 2000 年以降の新築集合住宅ではクラック開口比率が $20 \sim 40 \%$ 程度とい う高い值を示し，ストックーストック改修 新築，の順に隙間特性 值が小さくなる傾向がみられた。これは空や玄関ドアなど, 開口部 まわりの隙間の減少に連動している。

開口部まわり（空，玄関ドア）の隙間は，給気口など意図的な開 口に近い特性を示した。よって, 住戸の隙間特性から, 壁や床・天 井のクラックや，壁と床・天井間の隙間などバックグランドの隙間 は，レイノルズ数の低い狭く細長い隙間であると予想できる。

隙間特性值と相当隙間面積（C 值， $\mathrm{ELA}_{\mathrm{F} 10}$ ) の間に強い相関性は みられなかったが，隙間特性值とクラック開口比率の関係を 3 次式 で表現した場合には相関性がみられた。隙間特性值と隙間構成の関 
係から, 開口部まわりの改修による有効性を検討することができる。 今後は本手法が戸建住宅などに適用できるかどうかを検討して行 く予定である

謝 辞

本研究をおいて, 宮城高等専門学校の内海康雄教授には貴重なア ドバイスを, 神奈川大学の奥山博康教授からは最小二乗法のプログ ラムを提供して頂いた。また, 都市再生機構の小寺定典氏, 新菱冷 熱の深田賢氏, 東京理科大学大学院生の堀智朗君には, 気密測定に 関するデータ整理にご協力いただきました。ここに記して感謝の意 を表します。

注

注 1) 加圧法と減圧法, どちらを中心とした気密測定データを用いても本研 究における結果 (Fig.7 の 3 次式の各係数) にほとんど差がないことを事前 の検討により確認している。

注 2）指数式は, ISO をはじめとして欧米では $Q=C(\Delta P)^{\eta}$ のような形で表現さ れることが多い $(C$ は係数）。この場合, 指数 $\eta$ の範囲は $0.5 \leqq \eta \leqq 1$ とな るが, 式(1)では $1 \leqq n \leqq 2$ となる。本論文では指数の範囲が大きく, 精度的 に優れる ${ }^{8)}$ 式(1)を用いる。

注3）隙間特性が近い思われる湿式の $\mathrm{RC}$ 造と $\mathrm{SRC}$ 造の集合住宅を取り扱う。

注 4）改修が必要と思われる 1960 1970 年代に建設された集合住宅を「スト ック（集合住宅）」とし，改修後を「ストック改修（集合住宅）」，2003 年以降建築の集合住宅を「新築（集合住宅）」とする。

注 5) 式(1)の指数式および式(4)の 2 次式における最小二乗法による各係数の 算出には, 奥山が作成したプログラム 8)を使用したが, すべての測定值に 同じ重み $\left(w_{j}=1\right)$ とした。

\section{本論文に関連する既発表論文}

a）鳥海・倉渆・風間 : 集合住宅における隙間特性の評価法に関する研究, 日本建築学会大会学術講演論文集（北海道），pp.681-682，2013.8

\section{参考文献}

1）例えば, http://tightvent.eu/about, 参照 2014.9.17

2) ISO 9972:2006 Thermal performance of buildings -- Determination of air permeability of buildings -- Fan pressurization method, 2006.5

3) ASTM E779-10: Standard Test Method for Determining Air Leakage Rate by Fan Pressurization, ASTM International, 2010.1

4) ISO/FDIS 9972:2014(E) Thermal performance of buildings -. Determination of air permeability of buildings -- Fan pressurization method, 2014.11

5) 日本建築学会 環境工学委員会 空気環境運営委員会 換気・通風小委 員会 : シンポジウム「建物の気密性能を改めて考えるーその実態と評価・ 測定法一」, 日本建築学会, 2014.12

6）藤田・松下：単一ガス濃度測定による多室間の隙間の通気率および隙間 特性值の推定法の提案, 日本建築学会環境系論文集, No.697, pp.241-246, 2014.3

7) D. Etheridge and M. Sandberg: BUILDING VENTILATION: Theory and Measurement, JOHN WILEY \& SONS, 1996

8）奥山：気密測定法の現状と問題点, シンポジウム「建物の気密性能を改 めて考える一その実態と評価・測定法一」, pp.43-50, 日本建築学会, 2014.12

9）気密測定技術普及委員会 : 住宅の気密性能試験方法，建築環境・省エネ ルギー機構, 2004

10）鳥海・倉㴊・溝口・小寺 : 集合住宅の高気密化による室内負圧が住宅設 備機器に及ぼす影響, 空気調和・衛生工学会論文集, No.200, pp.11-18, 2013.9 


\title{
EVALUATION METHOD FOR LEAKAGE CHARACTERISTICS \\ OF BUILDING ENVELOPE OPENINGS IN MULTI-FAMILY DWELLINGS
}

\author{
Yoshihiro TORIUMI*, Takashi KURABUCHI** and Ruriko KANESHIGE ${ }^{* * *}$
}

\author{
* Assoc. Prof., School of Science and Engineering, Tokyo Denki University, Dr.Eng. \\ ** Prof., Faculty of Eng., Dept. of Architecture, Tokyo University of Science, Dr.Eng. \\ *** Formerly Student of Tokyo University of Science
}

\begin{abstract}
A leakage model can be used to predict the leakage characteristics of a room or a building from measurements. The models used for leakage prediction are shown in Table 1. The relationship between air flow rate and pressure difference is an exponential equation, commonly referred to as the power law for narrow openings, and is given by equation (1). The exponent $n$ is dependent on the Reynolds number as well as opening geometry (see Fig.1). The square law for large openings (e.g., purpose-provided openings such as air vents) is given by equation (2). The square law is based on the power law, and becomes the same as the power law when $n=2$. Generally, there are various types of opening geometries, and they may be combined in parallel or in series (see Fig.1). The parallel combination model is given by equation (3). The theoretical evidence for straight parallel openings with laminar flow favors the quadratic by equation (4) rather than the power law. The problem is to decide which flow equation is the most appropriate to adopt for combination. The parallel combination model can divide a specific effective leakage area (ELA, $\alpha \mathrm{A}$ ) into ELAs of narrow opening and large opening.
\end{abstract}

Table 2 presents the overall content of the dataset and contains the year of construction, size of the buildings and several variables related to this information. From daily life, the leakage is usually measured at pressure differences of approximately 10 to $50 \mathrm{~Pa}$. And in the case of high airtight dwellings, the leakage is measured at pressure differences of approximately 30 to $100 \mathrm{~Pa}$. Normally, the flow equation for series or parallel combination is not a power law. Figure 3 shows how the flow equations were fitted to the measured data on leakage (Table 3) of dwelling unit F1 (Fig.2). Table 4 presents the measured data of the apartment houses given in Table 2. The quadratic equation can provide good fits for the measured data of plots of $Q$ and $\Delta P$ (see Fig.4). The parallel combination model's ability to provide a good fit was equivalent to that of the power law.

As shown in Table 5, the ELA at 9.8 Pa (ELA ${ }_{10}$ ) of existing dwelling stocks (built in 1960-1970s) decreased by $30 \%$ or more by retrofitting. Retrofitted stocks and new constructions have leakage characteristics similar to narrow openings at low Reynolds number. In addition, differences in leakage characteristics are seen in the same building for different plans, as displayed in Fig.5. A plan with many windows relative to floor area is reeky. The flow characteristics of cracks around doors and window frames are similar to those of purpose-provided openings (see Table 6). Although these cracks are often narrow, it is because length is short. On the other hand, background openings (e.g., cracks in walls and ceilings) are narrow, and their width (depth) is much less than their length.

Figure 6 shows a low correlation linear fit between $\mathrm{ELA}_{10}$ per the floor area $\left(\mathrm{ELA}_{\mathrm{F} 10}\right)$ and "power law" exponent $n$. The relationship between " $\alpha \mathrm{A}_{N} /\left(\alpha \mathrm{A}_{N}+\alpha \mathrm{A}_{L}\right)$ " and exponent $n$ is obtained by regression weighted by measurements (see Fig.7), where " $\alpha \mathrm{A}_{\mathrm{N}}$ " means $\mathrm{ELA}_{10}$ of the narrow opening at low Reynolds number, and " $\alpha \mathrm{A}_{\mathrm{L}}$ " means $\mathrm{ELA}_{10}$ of the large opening. Therefore, " $\alpha \mathrm{A}_{N} /\left(\alpha \mathrm{A}_{\mathrm{N}}+\alpha \mathrm{A}_{\mathrm{L}}\right)$ " refers to the crack opening ratio. The exponent $n$ becomes small in the order of stocks $(+)$, retrofitted stocks $(\boldsymbol{\Lambda})$, and new constructions between 2003 and $2007(\bigcirc)$, and the crack opening ratio becomes high in the same order. This method is effective in the evaluation of retrofitting and leakage characteristics of apartments. 